INDEPENDENT JOURNAL OF MANAGEMENT \& PRODUCTION (IJM\&P)

http://www.ijmp.jor.br

v. 11, n. 1, January-February 2020

ISSN: 2236-269X

DOI: 10.14807/ijmp.v11i1.990

\title{
ANAL YTICAL HIERARCHY PROCESS - BOCR APPLIED FOR THE BEST LEAN PROJECT SELECTION FOR PRODUCTION LINES
}

\author{
José Antonio de Miranda Lammoglia \\ Universidade Federal Fluminense, Brazil \\ E-mail: jalammoglia@gmail.com \\ Nilson Brandalise \\ Universidade Federal Fluminense, Brazil \\ E-mail: nilson_01@yahoo.com.br \\ Cecilia Toledo Hernandez \\ Universidade Federal Fluminense, Brazil \\ E-mail: ctoledo@id.uff.br \\ Submission: $1 / 24 / 2019$ \\ Revision: 2/27/2019 \\ Accept: 3/28/2019
}

\section{ABSTRACT}

The scenario of global competitiveness demands more and more of the organizations the search for continuous improvement. For survival, in the face of adverse market conditions, modern production management strategies are essential to make production processes increasingly efficient, lean and sustainable, minimizing losses in their production systems. In this sense, when thinking about changes in production lines, in search of improvements in their process, criteria that provide Benefits, Opportunities, Costs and Risks (BOCR) should be considered. In this way, managers and executives should rely on tools and methods that allow them to guide their decisions in a clear way. The objective of this work is to apply a method of Decision Making with Multiple Criteria to the alternatives of investment projects in production lines in Lean Manufacturing concept. As a general result, it was possible to observe the applicability of the AHP BOCR method for the decision-making case involving several criteria and subcriteria for choosing the Lean investment project in the steel environment, the preferred alternative being the discontinuity of the production line 1 and the absorption of their respective production volume by production lines 2 and 3 through investments in them.

Keywords: Lean Manufacturing; AHP BOCR; project selection. 
DOI: 10.14807/ijmp.v11i1.990

\section{INTRODUCTION}

The scenario of global competitiveness demands more and more of the organizations the search for continuous improvement. For survival, in the face of adverse market conditions, modern production management strategies are essential to make production processes increasingly efficient, lean and sustainable, minimizing losses in their production systems.

A simple decision that involves few criteria is possible to be taken by a person, however the human brain is not able to ponder decisions when they involve many criteria. In this way, managers and executives should rely on tools and methods that allow them to guide their decisions in a clear way.

The decision about the completion of a project usually requires investigating the positive (benefits) and negatives (costs) of this project and an attempt to express them in monetary terms. If there are several projects to choose from, these projects will usually be sorted according to their respective benefit / cost coefficients. The problem is that benefits and costs are often difficult to express in monetary terms, especially when some of the benefits or costs are intangible.

The Analytic Hierarchy Process (AHP), developed by Saaty, has been advocated as an approach that not only can deal with tangibles and intangibles but also helps to organize all the aspects involved in a hierarchical structure where the aspects of benefit or cost act as criteria and projects as alternatives. You must compare the importance of cost criteria in the cost hierarchy and the benefit criteria in the separate hierarchy of benefits in pairs.

These processes produce weights of relative criteria expressed in a derived ratio scale, usually normalized to the sum of the unit for each family of criteria in each hierarchy. Alternative projects are compared in pairs for each criterion at the lowest level of each hierarchy; their derived priorities are expressed in a ratio scale as well, again usually normalized to the sum of the unit by criterion (WIJNMALEN, 2007).

The nature of the problem is: How to define the best alternative for investment projects based on the Lean concept?

The objective of this work is to apply a method of Decision Making with Multiple Criteria to the alternatives of investment projects in production lines in Lean Manufacturing concept. 
DOI: 10.14807/ijmp.v11i1.990

The justification for this work is given by the need to reduce increasingly the wastes in the productive processes to maintain the competitiveness in the market. Finishing lines in the steel environment were chosen for the study.

This work has the following organization: first part consists of bibliographical research; choice of expert group; definition of the criteria together with the experts; judgment and prioritization of each criterion; data collect; project development and results analysis.

\section{LITERATURE REVIEW}

\subsection{Lean Manufacturing}

The incontrovertible goal of Lean Manufacturing is to reduce / eliminate waste of the process, which is any resource used for any purpose other than value creation (GHOBADIAN et al., 2018). It was created to increase productivity by reducing or eliminating waste through activities that do not add value within processes. Its success is due to the Toyota engineers who, using an innovative concept of production flow (pull production), supply and supply of components (Junt-in-Time and Kanban), have developed a new production standard from modifications made in the model of mass production.

The Lean philosophy made it possible to reduce operational costs by increasing the efficiency of the production system, eliminating wastes (Muda) with waiting, excess inventory, overproduction, movements, transportation, overprocessing, defects, underutilized people, and implementing an improvement system (Kaizen), specify value and standardize the process (MEDEIROS; SANTANA; GUIMARÃES, 2017).

\subsubsection{Muda}

Muda is a Japanese term that literally means: futility, idleness or waste. The term was first introduced in the 1950s by Taiichi Ohno, a Japanese engineer at Toyota Motor Corporation. In the 1950s, Eiji Toyoda and Taiichi Ohno visited American auto companies several times. His main finding was that there was a lot of waste everywhere, including Ford, which was recognized as the most efficient car manufacturer in the world at the time.

There was a waste of human power, efforts, materials, space and time. Muda was a key concept in the design and implementation of the Toyota Production System, and the reduction and minimization of waste was recognized as the most effective way to increase profitability (SUÁREZ-BARRAZA et al., 2016). 
DOI: 10.14807/ijmp.v11i1.990

Waste is defined as any activity that adds cost to a product or service without adding value from the customer's perspective. Ohno identified seven unique types of waste within the Toyota Production System (TPS), Womack and Jones added the eighth type of waste (MOSTAFA; DUMRAK; SOLTAN, 2015).

Table 1 shows how waste sources and their definitions are classified.

Table 1: Sources of waste and their definitions

\begin{tabular}{ll}
\hline Sources of waste (muda) & Definition \\
Defects & Any type of rework or repair and excessive scrap. \\
Excess inventory & Excess inventory of parts, spare parts or finished products. \\
Wait & Inactive production machines due to lack of inventory, processing \\
& delays, scheduling problems, capacity bottlenecks, etc. \\
Transport & Move finished products or parts unnecessarily over long distances. \\
Inappropriate processing & Unnecessary steps to produce goods due to inadequate design, \\
& $\begin{array}{l}\text { limitations of available equipment, excessively high quality } \\
\text { standards, etc. } \\
\text { Overproduction }\end{array}$ \\
Movements & $\begin{array}{l}\text { Excessive in terms of frequency and distance or unnecessary } \\
\text { movement of people, parts or finished products. }\end{array}$ \\
Employee underutilization & Creativity and skills of unused employees to improve processes and \\
& practices, this refers to wasting the available knowledge, experience \\
& or skill of the team / workforce underutilizing them or not using them \\
in the appropriate department.
\end{tabular}

Source: (MOSTAFA; DUMRAK; SOLTAN, 2015)

\subsection{Multicriteria Decision Making}

Decision making is the process of identifying a problem or an opportunity and defining an action plan to resolve it. A problem can be characterized when the current condition of a situation is different from the desired condition. An opportunity occurs when circumstances provide a chance for the individual / organization to achieve its goals. Decision making usually occurs in a dynamic scenario, so the good decision is one that solves a problem based on multicriture decision support. Over time, that scenario changes, and better decisions, based on that same basis, may emerge (PEREIRA; BRANDALISE; MELLO, 2017).

The development of new methods began in the 60's with the objective of finding optimal solutions to decision support. The application of multicriteria decision-making techniques, also known as multiple-criteria-decision-making (MCDM), has grown extensively in the last decades, as well as the number of techniques to evaluate the alternatives and select the best 
DOI: 10.14807/ijmp.v11i1.990

ones. The scientific literature mentions that more than 70 MCDM techniques are available to help the decision maker make an appropriate decision at different stages of the life cycle, spreading their wings across the fields of science, business, production, and engineering (MUFAZZAL; MUZAKKIR, 2018).

The inconsistent criteria have a different nature and fall into one of two categories: Ordinal method, where the information of the alternatives is qualitative in nature and requires the decision maker to assign scores to each alternative, based on how much it fulfills a specific criterion; and the Cardinal method, where the information about the alternatives is quantitative and can be used directly for the decision process. The MCDM is a subset of operational research that explicitly assesses several inconsistent criteria in decision making (SHAHSAVARI; KHAMEHCHI, 2018).

MCDM is looking for an ideal solution from a variety of options to meet most if not all criteria. This tool helps improve the quality of the decision making it more comprehensive, rational and effective. The method can also make it easier for decision-makers to negotiate, quantify and communicate priorities (KHAN, 2018).

\subsubsection{Analytical Hierarchy Process (AHP)}

The Analytical Hierarchy Process (AHP) is a multicriteria decision-making approach and was presented by Satty in 1980. The main purpose of AHP is to decompose a problem into smaller constituent parts. By diluting the problem, the decision maker can focus on the limited number of items. The two phases of the AHP are the evaluation of the components in the hierarchy and the design of the hierarchy (GNANAVELBABU; ARUNAGIRI, 2018).

AHP is a widely used tool by researchers working in the field of decision making to select the best alternatives among various options when judgment has to be based on a wide range of parameters. AHP basically converts the preference obtained from individual expert into ratio scale weights that can be combined into a linear additive weight for each available alternative. The result finally obtained is used to compare and classify the alternatives and, therefore, simplifies the choice of the decision maker (CAMILO et al., 2017).

Researchers and professionals from different areas of engineering and management recognize AHP as one of the most competent techniques to deal with complex decision problems. Using the AHP, MCDM problems are broken down into several subproblems through hierarchical levels, where each level describes the set of criteria for each subproblem. The AHP technique is a MADM (multi-attribute decision making) technique that uses the 
DOI: 10.14807/ijmp.v11i1.990

additive weighting process, where different significant parameters are valued in their relative significance (YADAV; SETH; DESAI, 2018).

\subsubsection{BOCR Approach}

In general, in many decision-making problems, there are four types of interests that must be taken into account: benefits, opportunities, costs and risks, henceforth called BOCR merits. Merit Benefit (B) is opposed to Cost (C), while Opportunity merit (O) is opposed to Risk (R). The BOCR merits introduce the notion of negative priorities ( $\mathrm{C}$ and $\mathrm{R}$ ), as well as positive priorities ( $\mathrm{B}$ and $\mathrm{O}$ ), to decision problems. The Benefit shows which is the most beneficial alternative and the Opportunity merit, which alternative has the greatest potential benefits. The Cost shows which alternative is the most costly and Risk, the alternative with the greatest potential cost. (SILVA; NASCIMENTO; BELDERRAIN, 2010).

A complete BOCR analysis is similar to a SWOT analysis, in which not only the strengths (S) of a company but also the opportunities (O) are taken into account, such as good chances of entering a new market and other favorable situations. Opportunities in the BOCR analysis often capture positive expectations about future profits and revenues, whether the benefits represent current revenue or those profits of which we are sure. Likewise, the weaknesses (W) of a company may not be sufficient to address all the negative aspects in the SWOT analysis; threats (T) concerning competition or society must also be addressed.

The risks in the BOCR analysis are supposed to capture the expected negative consequences of future events, while costs represent losses and negative consequences of which we are sure. Therefore, BOCR analysis is richer than a simple BC analysis, although many of the aspects that define factors and their relationships are often difficult to specify and quantify. Many applications of BOCR analysis are offered where a network model, such as Analytic Network Process (ANP), for each of the BOCR factors is configured instead of a hierarchy (AHP). This allows us to model interrelations between the elements that define each of the four factors (WIJNMALEN, 2007).

\section{METHODOLOGY AND METHODS}

For this study, the steps followed are shown in figure 1. 
DOI: 10.14807/ijmp.v11i1.990

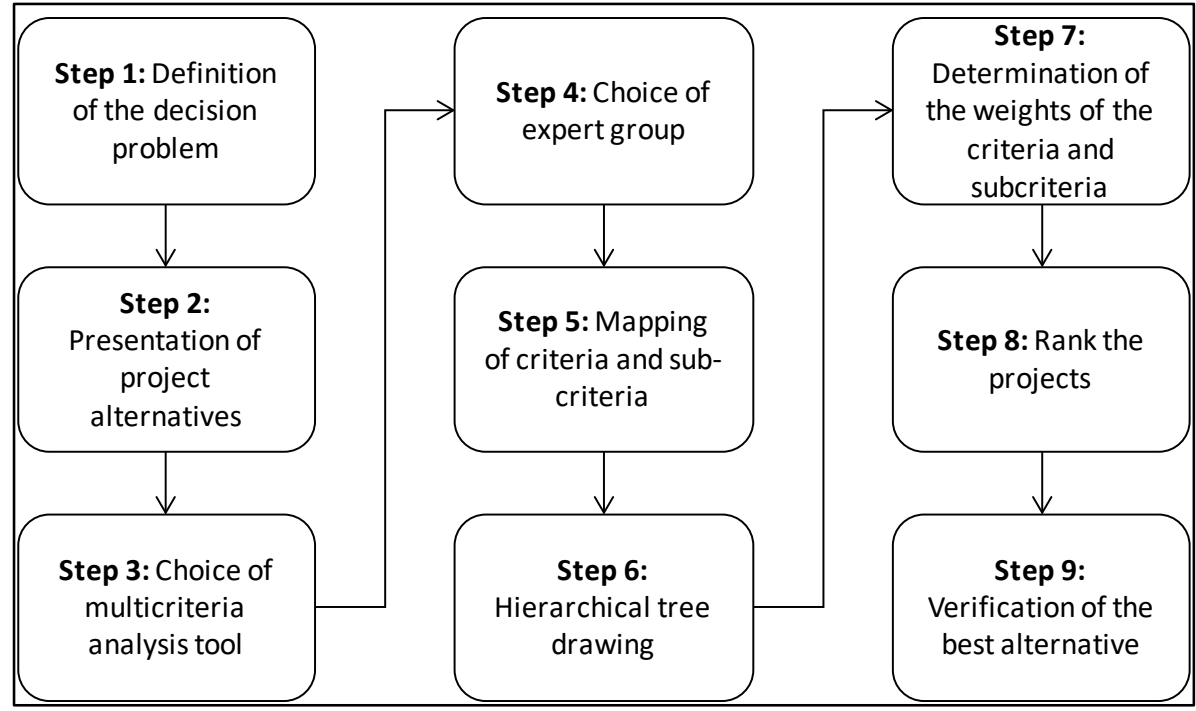

Figure 1: Method adopted

Source: Prepared by the authors (2019)

The decision problem deals with the selection of Lean investment projects and the common objective of all projects is to reduce from three to two production lines, maintaining the same total production volume, eliminating waste and working the muda concept (Lean Manufacturing). Three design alternatives were considered for this study:

- Project 1: the discontinuity of production line 1 and the absorption of its respective volume of production by production lines 2 and 3 through investments in them.

- Project 2: the discontinuity of production line 3 and the absorption of its respective volume of production through lines 1 and 2 through investments in them.

- Project 3: the discontinuity of production lines 1 and 3 and the absorption of their respective production volumes through the acquisition of a new line, known as 4 .

Each of the production lines has different production capacity, both in volume and product mix.

The tool chosen for the multicriteria analysis was AHP BOCR and the group of specialists chosen was from managers of the same department of a steel company.

Through structured brainstorming, the subcriteria presented in Table 2, as well as their respective definitions, were proposed and selected. 
INDEPENDENT JOURNAL OF MANAGEMENT \& PRODUCTION (IJM\&P)

http://www.ijmp.jor.br

v. 11, n. 1, January-February 2020

ISSN: 2236-269X

DOI: 10.14807/ijmp.v11i1.990

Table 2: Definition of subcriteria

\begin{tabular}{|c|c|c|}
\hline BOCR & Subcriteria & Definition \\
\hline \multirow{3}{*}{ Benefits } & Labor Productivity (LP) & Productivity in tonnes per man. \\
\hline & Area (AR) & Available area. \\
\hline & Logistics (LOG) & $\begin{array}{c}\text { Logistics of supply and outflow of production } \\
\text { lines. }\end{array}$ \\
\hline \multirow{4}{*}{ Opportunities } & Revenue Increase (RI) & Increased revenue from new product offerings. \\
\hline & Improvement of product quality (IPQ) & $\begin{array}{l}\text { Reduction of rework and discards due to } \\
\text { defects caused by the production line. }\end{array}$ \\
\hline & & Ease of being maintained obeying \\
\hline & Maintainability (MAI) & $\begin{array}{l}\text { manufacturing standards, having spare parts in } \\
\text { the market and assists to apply services to that } \\
\text { particular product. }\end{array}$ \\
\hline \multirow{3}{*}{ Costs } & Cost of processing (CP) & $\begin{array}{c}\text { Cost of maintenance and operation (fixed and } \\
\text { variable). }\end{array}$ \\
\hline & Investment (INV) & Capital needed for all stages of the project. \\
\hline & Payback (PAY) & Return on investment time. \\
\hline \multirow{3}{*}{ Risks } & Challenges for investment (CIN) & $\begin{array}{c}\text { Difficulties in getting the capital needed for } \\
\text { investment. }\end{array}$ \\
\hline & Problems of design (PD) & Delay for startup and design flaws. \\
\hline & Spare Parts Management (SPM) & $\begin{array}{l}\text { Inventory, material registration, classification, } \\
\text { acquisition lead time, etc. }\end{array}$ \\
\hline
\end{tabular}

Source: Prepared by the authors (2019)

After defining the criteria and subcriteria, the hierarchical tree was drawn and can be seen in figure 2.

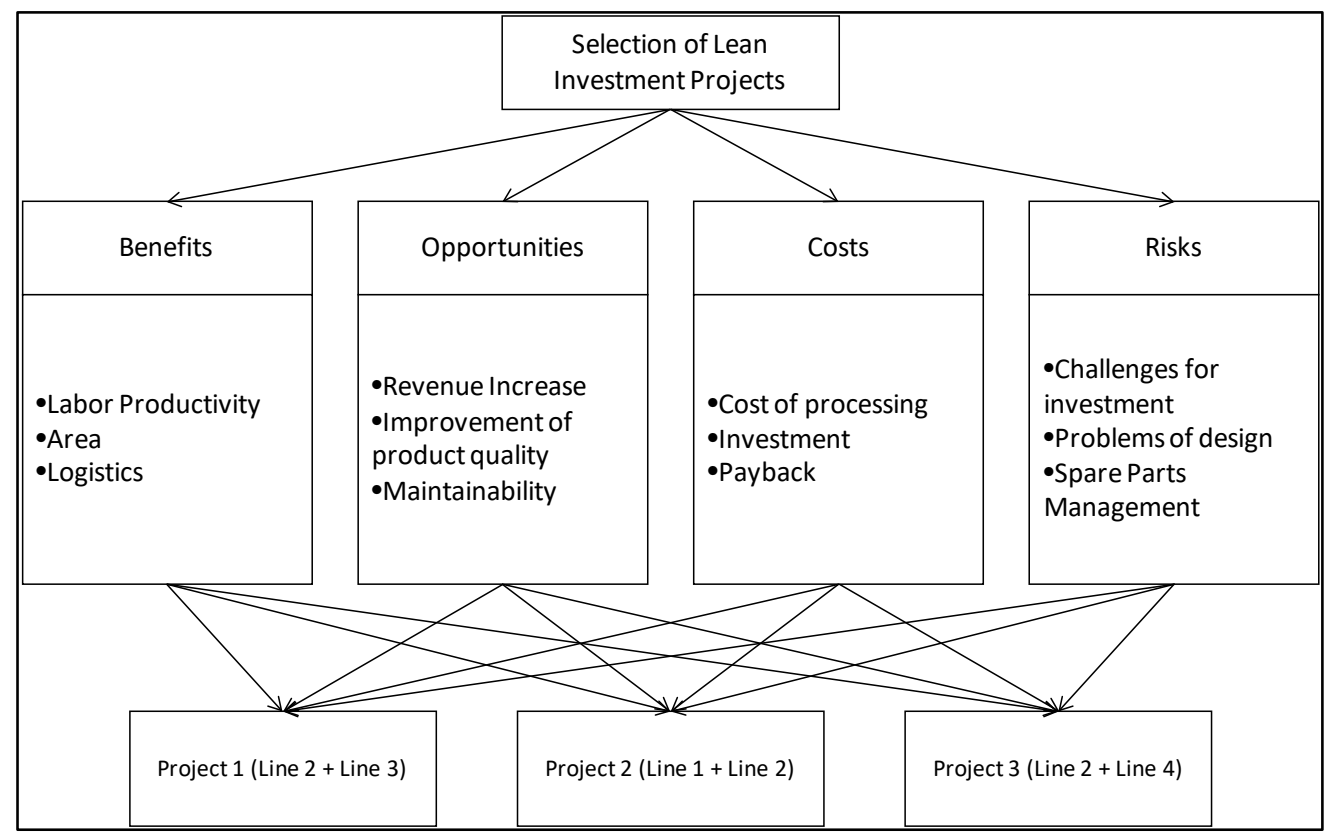

Figure 2: Hierarchical tree

Source: Prepared by the authors (2019)

The weights of the criteria and subcriteria were determined by means of a parity comparison matrix using the Saaty scale completed by the group of experts and the consistency ratio was 0.09907. 
ISSN: 2236-269X

DOI: $10.14807 /$ ijmp.v11i1.990

After determining the weights of the criteria and subcriteria, the projects were ranked and then the best alternative was verified.

\section{RESULTS}

After the interviews with the experts, the generated diagrams were converted into the matrix of judgments of each criterion and the priorities of each subcriteria as can be seen in Table 3.

Table 3: Aggregate matrix of sub-criteria judgments

\begin{tabular}{ccccccccc}
\hline Criteria & Subcriteria & EXP.1 & EXP.2 & EXP.3 & EXP.4 & EXP.5 & EXP.6 & Priority \\
\hline \multirow{4}{*}{ B } & LP & 0,0255 & 0,0435 & 0,0875 & 0,0376 & 0,0514 & 0,0330 & 0,0464 \\
& AR & 0,0332 & 0,0665 & 0,0121 & 0,0308 & 0,0597 & 0,0210 & 0,0372 \\
& LOG & 0,0301 & 0,0393 & 0,0174 & 0,0189 & 0,0514 & 0,0268 & 0,0306 \\
\hline \multirow{3}{*}{ O } & RI & 0,1544 & 0,0750 & 0,1522 & 0,1633 & 0,1569 & 0,1005 & 0,1337 \\
& IPQ & 0,1407 & 0,0371 & 0,1246 & 0,0591 & 0,0667 & 0,1527 & 0,0968 \\
& MAI & 0,0800 & 0,0298 & 0,1337 & 0,0854 & 0,0750 & 0,0662 & 0,0784 \\
\hline \multirow{3}{*}{ C } & CP & 0,1380 & 0,0964 & 0,1754 & 0,1633 & 0,1194 & 0,1042 & 0,1328 \\
& INV & 0,1294 & 0,1338 & 0,0633 & 0,0921 & 0,0750 & 0,0960 & 0,0983 \\
& PAY & 0,0952 & 0,1904 & 0,0621 & 0,1172 & 0,1528 & 0,2349 & 0,1421 \\
\hline \multirow{2}{*}{ R } & CIN & 0,0567 & 0,1985 & 0,0364 & 0,0894 & 0,0583 & 0,0521 & 0,0819 \\
& PD & 0,0689 & 0,0581 & 0,0350 & 0,0932 & 0,0583 & 0,0504 & 0,0607 \\
& SPM & 0,0480 & 0,0316 & 0,1004 & 0,0498 & 0,0750 & 0,0622 & 0,0612 \\
\hline
\end{tabular}

Source: Prepared by the authors (2019)

Given the aggregate priorities, the overall priorities of the criteria and subcriteria were calculated as shown in figure 3. The aggregate priority of each sub-criterion was compared against all criteria, providing the overall standardized priority.

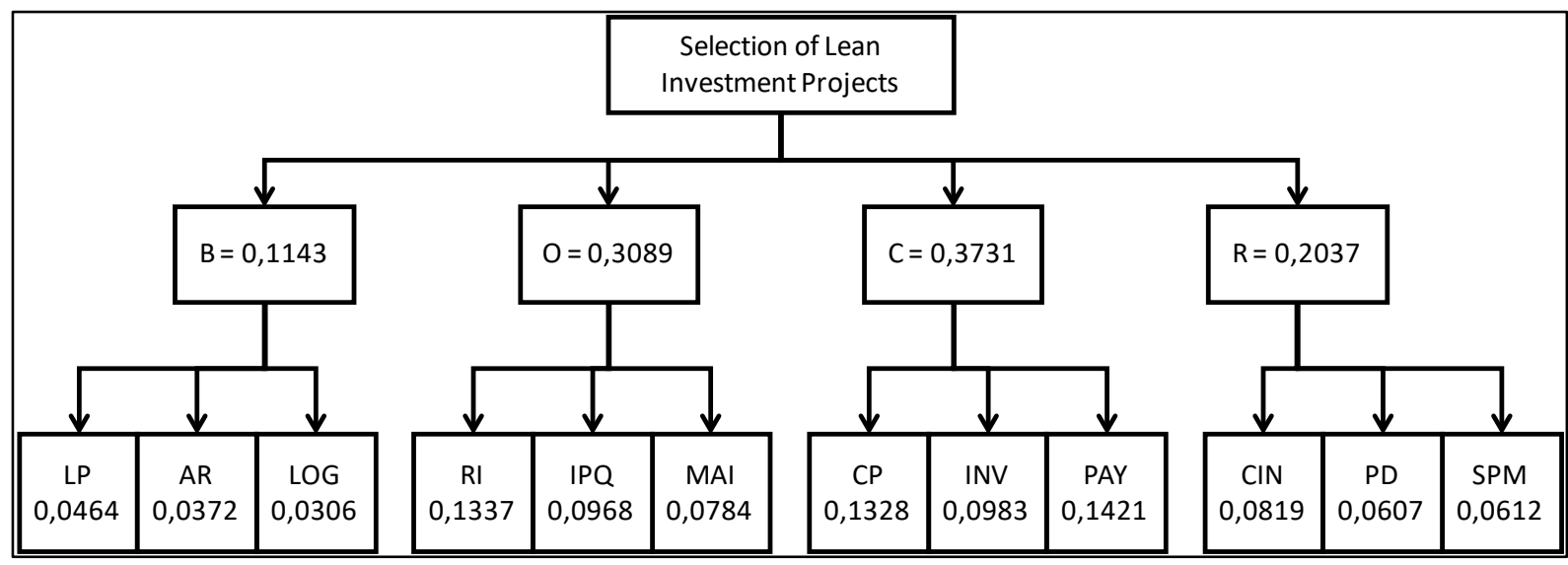

Figure 3: Final priority of criteria and sub-criteria Source: Prepared by the authors (2019)

In this stage of work, the intensity levels of each subcriteria were determined for each project, according to Table 4. 
DOI: 10.14807/ijmp.v11i1.990

Table 4: Project Priority Calculation

\begin{tabular}{|c|c|c|c|c|c|}
\hline Criteria & Subcriteria & $\begin{array}{c}\text { Global } \\
\text { Priority }\end{array}$ & $\mathbf{P 1}$ & $\mathbf{P} 2$ & P3 \\
\hline \multirow{3}{*}{ B } & $\mathrm{PMO}$ & 0,0464 & 1,00 & 0,00 & 0,44 \\
\hline & AR & 0,0372 & 0,00 & 1,00 & 1,00 \\
\hline & LOG & 0,0306 & 0,00 & 1,00 & 1,00 \\
\hline \multirow{3}{*}{$\mathrm{O}$} & AUR & 0,1337 & 0,00 & 0,00 & 1,00 \\
\hline & MQ & 0,0968 & 0,50 & 0,00 & 1,00 \\
\hline & MAN & 0,0784 & 0,50 & 0,00 & 1,00 \\
\hline \multirow{3}{*}{$\mathrm{C}$} & $\mathrm{CT}$ & 0,1328 & 0,67 & 0,00 & 1,00 \\
\hline & INV & 0,0983 & 1,00 & 1,00 & 0,00 \\
\hline & PAY & 0,1421 & 1,00 & 1,00 & 0,00 \\
\hline \multirow{3}{*}{$\mathrm{R}$} & DIN & 0,0819 & 1,00 & 1,00 & 0,00 \\
\hline & PP & 0,0607 & 1,00 & 0,00 & 0,00 \\
\hline & GS & 0,0612 & 1,00 & 1,00 & 0,00 \\
\hline \multirow{3}{*}{\multicolumn{2}{|c|}{ Priority }} & Total & 0,0869 & 0,0752 & 0,0823 \\
\hline & & Normalized & 0,3557 & 0,3076 & 0,3367 \\
\hline & & Ranking & 1 & 3 & 2 \\
\hline
\end{tabular}

After all the results, the following standard priorities were verified: project alternative P1 - 0,3557, project alternative P2 - 0,3076 and alternative project P3 - 0,3367.

\section{CONCLUSION}

The search for continuous improvement and the need to make production processes increasingly efficient, lean and sustainable, mean that companies adopt modern production management strategies, minimizing losses. The applied method was effective in the organization and structuring of the criteria and subcriteria for the selection of projects in Lean concept.

The selected alternative was $\mathrm{P} 1$, with a normalized priority of 0,3557 and proposing the discontinuity of production line 1 and the absorption of its respective volume of production by production lines 2 and 3 through investments in themselves. The choice of this alternative offers the best option to increase the productivity of the workforce, as fewer employees will be needed to operate the equipment, maintaining the volume of production. It also offers the least risk of design problems, since investments will be directed towards increasing the productivity of lines 2 and 3, with few technological and operational changes. On the other hand, it offers the greatest challenges in area availability and logistics to supply and dispose of production.

As a suggestion for future work, it is interesting to include more alternatives of projects, more subcriteria and the verification of the relation between them, adopting the Analytic Network Process (ANP) model, making the method of project selection more complex. 
DOI: 10.14807/ijmp.v11i1.990

\section{REFERENCES}

CAMILO, H. F. et al. (2017) Assessment of photovoltaic distributed generation - Issues of grid connected systems through the consumer side applied to a case study of Brazil.

Renewable and Sustainable Energy Reviews, v. 71, n. December 2016, p. 712-719.

GHOBADIAN, A. et al. (2018) Examining legitimatisation of additive manufacturing in the interplay between innovation, lean manufacturing and sustainability. International Journal of Production Economics, n. July 2017, p. 1-12.

GNANAVELBABU, A.; ARUNAGIRI, P. (2018) Ranking of MUDA using AHP and Fuzzy AHP algorithm. Materials Today: Proceedings, v. 5, n. 5, p. 13406-13412.

KHAN, M. I. (2018) Evaluating the strategies of compressed natural gas industry using an integrated SWOT and MCDM approach. Journal of Cleaner Production, v. 172, p. 10351052.

MEDEIROS, H. DA S.; SANTANA, A. F. B.; GUIMARÃES, L. DA S. (2017) O uso dos métodos de custeio nas indústrias de manufatura enxuta: uma análise da literatura. Gestão \& Produção, v. 24, n. 2, p. 395-406.

MOSTAFA, S.; DUMRAK, J.; SOLTAN, H. (2015) Lean Maintenance Roadmap. Procedia Manufacturing, v. 2, n. February, p. 434-444.

MUFAZZAL, S.; MUZAKKIR, S. M. (2018) A new multi-criterion decision making (MCDM) method based on proximity indexed value for minimizing rank reversals. Computers and Industrial Engineering, v. 119, n. November 2017, p. 427-438.

PEREIRA, A. S. A.; BRANDALISE, N.; MELLO, L. C. B. DE B. (2017) Aplicação do método AHP na seleção de terrenos para edificações comerciais na cidade do Rio de Janeiro. Sistemas \& Gestão, v. 11, n. 4, p. 410.

SHAHSAVARI, M. H.; KHAMEHCHI, E. (2018) Optimum selection of sand control method using a combination of MCDM and DOE techniques. Journal of Petroleum Science and Engineering, v. 171, n. January, p. 229-241.

SILVA, A. C. S.; NASCIMENTO, L. P. A. DA S.; BELDERRAIN, M. C. N. (2010) Aplicação do método analytic network process (ANP) com abordagem BOCR no contexto militar. Simpósio De Pesquisa Operacional E Logística Da Marinha, p. 11.

SUÁREZ-BARRAZA, M. F. et al. (2016) In search of “Muda” through the TKJ diagram. International Journal of Quality and Service Sciences, v. 8, n. 3, p. 377-394.

WIJNMALEN, D. J. D. (2007) Analysis of benefits, opportunities, costs, and risks (BOCR) with the AHP-ANP: A critical validation. Mathematical and Computer Modelling, v. 46, n. 7-8, p. 892-905.

YADAV, G.; SETH, D.; DESAI, T. N. Prioritising solutions for Lean Six Sigma adoption barriers through fuzzy AHP-modified TOPSIS framework. [s.l: s.n.]. v. 9 